\title{
Ekološko-geografska determiniranost koloniziranja Slavonije u 18. stoljeću
}

\begin{abstract}
Krajem 17. stoljeća započela je nova kolonizacija Slavonije koja ujedno označava i novu fazu antropizacije slavonskog prostora. Ta faza antropizacije trajat će sve do modernizacijskih procesa polovinom 19. stoljeća. Novodoseljeno stanovništvo najprije se uselilo u brojna opustjelih sela, ali je već 1690-ih započelo i osnivanje novih naselja. Ona koja su napuštena tijekom Velikog bečkog rata već su se prije u prošlosti dokazala kao dobra za naseljavanje i poljoprivrednu djelatnost, a za novoosnovana naselja tek je vrijeme trebalo dokazati jesu li za to pogodna ili nisu. Stoga je za ovo razdoblje antropizacije i naseljavanja Slavonije naročito znanstveno zanimljivo i važno promatrati sudbinu novoosnovanih naselja. Naseljenici su u Slavoniju dolazili iz raznih krajeva - ponajviše iz Bosne i Srbije, ali i iz Like i Gorskog kotara, središnje Hrvatske te iz Bačke i Baranje. Zabilježena su i doseljavanja njemačkih kolonista, ali u relativno malom broju. U ovome radu analiziraju se okolnosti koloniziranja šumskog kraja Đakovačkog vlastelinstva te kolonizacija Nijemaca u Osijek i Rumu. Ta dva primjera kolonizacije Slavonije egzemplarni su tipovi naseljavanja šumskog i ravničarsko-močvarnog područja te pokazuju stvarne utjecaje ekološko-geografske uvjetovanosti koloniziranja Slavonije u 18. stoljeću, odnosno u kolikoj je mjeri kolonizacija bila određena prostorom i biljnim pokrovom (šumama), ali i općim zdravstvenim (ne)prilikama koje su utjecale na uvjete života, ponajviše prisutnošću malarije u močvarnim područjima.
\end{abstract}

\section{Uvod}

Nakon završetka Velikog bečkog rata (1683-1699), Slavonija je ponovno ušla u društveni i gospodarski krug srednje Europe. ${ }^{1}$ No još čitavo 18. stoljeće ona je bila zemlja šuma i močvara, slabo naseljena i gospodarski nerazvijena. Iako su ljudi naseljavali Slavoniju već u rano pretpovijesno doba, sve do polovine 18 . stoljeća veći je dio njezine površine bio neobrađen (nekultiviran), odnosno nije bio antropiziran. Pri tome pojam antropizacije treba razumjeti kao ukupno djelovanje

\footnotetext{
Pod Slavonijom ovdje smatram čitav prostor triju slavonsko-srijemskih županija i triju pukovnija Slavonske vojne granice. Tako u prostor Slavonije uključujem i Srijem, što odgovara poimanju Slavonije i Srijema u 18. stoljeću. Naime, Srijemska županija nastupala je i prema Hrvatskom i prema Ugarskom saboru kao dio Slavonije, a Petrovaradinska pukovnija pripadala je Slavonskoj vojnoj granici. Pojmom „slavonski Provincijal“"za prostor civilne Slavonije nakon odvajanja od Slavonske vojne granice 1702. godine koristim se prema radovima povjesničara Ive Mažurana.
} 
čovjeka na prirodu. Antropizacija tako označava čovjekovo prilagođavanje okoliša svojim potrebama, ali nužno uključuje i rušenje, tj. narušavanje, pa i zagađivanje prirode i prostora koji ga okružuju.

Dosadašnja je historiografija utvrdila da je u Slavoniji tijekom 18. stoljeća došlo do naglog porasta stanovništva, što je dijelom bilo posljedica prirodnog prirasta, ali i doseljavanja. Povećavanje stanovništva, naročito slučajevi pojedinačnih ili grupnih doseljavanja, otvaraju pitanje koliko je sâm prirodni okoliš određivao tempo i prostornu disperziju porasta stanovništva, naročito naseljavanja. Napuštena Slavonija s početka 18. stoljeća trebala je u određenoj mjeri biti ponovno „osvojena“. Prirodni okoliš (tlo, klima, biljni i životinjski svijet) određuju uvjete života i gospodarsku aktivnost ljudi. Ta je uvjetovanost naročito bila izražena u vrijeme predmodernog agrarnog društva. Borna Fürst-Bjeliš o tome je prije više od dvadest godina napisala sljedeće: „Different types of natural environments will have varying influences on a primary concentration of population, on location and

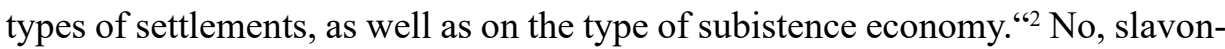
ska priroda nije bila „divljina“, ona divljina o kojoj je pisao Fernand Braudel u svojemu djelu Struktura svakidašnjice. ${ }^{3}$ Slavonija nije bila poput Sibira, Australije ili Novog Zelanda, neistraženih prostranstava koje je otkrio i osvojio europski čovjek u ranome novom vijeku. Ona je tisućama godina bila nastanjivana, u doba Rimskog Carstva i relativno gusto naseljena, ali je uslijed stoljeća društvene nestabilnosti i brojnih ratova na početku toga 18 . stoljeća bila manje-više pusta. A kad nema ljudi, priroda ponovno preuzme prostor. Stoga će u ovome radu primarni cilj biti analiza prirodnog okoliša kao ograničavajućeg čimbenika u porastu stanovništva, naročito naseljavanja. Fokus interesa usmjeren je na dva prostorna čimbenika - šume i močvare. Antropizacija šumskih i močvarnih prostora bila je prisutna u Slavoniji još od vremena starog Rima, a važnost promjena koje je svojim radom izvršio čovjek u takvom okolišu istaknuli su i francuski povjesničari okoliša Robert Delort i François Walter. Oni su naročito istaknuli važnost ljudske djelatnosti za pojavu i širenje zaraznih bolesti: „Seoba stanovništva, poljodjelska djelatnost, iskrčavanje šuma, prenapučenost stanovništva, smanjena otpornost imunološkog sustava, kontakti s ljudskim ili životinjskim izolatima, sve ljudske aktivnosti odgovorne su u neku ruku za brzo širenje, u naglim provalama, zaraznih bolesti. “4 Stoga ekološko-epidemiološke prilike u Slavoniji tijekom 18. stoljeća treba gledati i iz perspektive tadašnjeg ljudskog djelovanja na okoliš.

Novi stanovnici Slavonije tijekom 18. stoljeća pretežito su se naseljaavali u već nastanjena sela s kultiviranim poljoprivrednim površinama. Zato su iz perspektive istraživanja ekološko-geografske uvjetovanosti naseljavanja Slavonije u to doba

FÜRST-BJELIŠ 1998: 149.

BRAUDEL 1992: 94-96.

4 DELORT I WALTER 2002: 144. 
najzanimljivije dvije situacije koje će se analizirati u ovome radu: osnivanje novih sela u šumskim prostorima kao ,osvajanje“ šumskog prostora i naseljavanje ravničarsko-močvarnih prostora kao „osvajanje“"nezdravih (malaričnih) prostora.

\section{Smjerovi naseljavanja Slavonije u 18. stoljeću}

Slavonija je nakon sloma osmanske vlasti i iscrpljujućeg Velikog bečkog rata (1683-1699) ostala raseljeni pogranični prostor. Prema procjenama Ive Mažurana, područje od Male Vlaške do vukovarskog distrikta (dakle, Slavonija bez većeg dijela Srijema) brojilo je 1698 . godine između 70.000 i 80.000 stanovnika. ${ }^{5}$ Novostečeno (neoaquistica) područje Habsburgovci su namjeravali urediti prema potrebama Habsburške Monarhije. Već 1702. godine osnovana je Slavonska vojna granica, koja je trebala vojno osiguravati Monarhiju prema Osmanskom Carstvu. Ostatak Slavonije pretvoren je u civilni teritorij (Provincijal) te je u sljedećim desetljećima razdijeljen na brojna vlastelinstva.

Ogromni prostori Slavonije bili su tada nenastanjeni, prekriveni šumama i močvarama. Štoviše, neka su naselja ostala pusta sve do polovine 18. stoljeća. U takvim su slučajevima mnogi antropizirani prostori ponovno zarasli u šume. Opustjelost Slavonije bila je dramatično velika. Prema Ivi Mažuranu, uoči Velikog bečkog rata na prostoru Slavonije (točnije, Slavonije sa zapadnim Srijemom) bilo je 736 naseljenih mjesta, a prema komorskom popisu iz 1698., na istom je području bilo 491 naseljeno naselje i više od 240 napuštenih sela. ${ }^{6}$ Mažuranovo objavljivanje komorskog popisa slavonskih naselja iz 1698. godine vrlo je važno i pokazuje tadašnju demografsku situaciju. Prave razmjere demografskog pada pokazuju neki distrikti u kojima je broj opustjelih sela bio izuzetno velik. Primjerice, u Distriktu Valpovo bilo je 14 naseljenih i 30 pustih sela, u Distriktu Orahovica 27 naseljenih i 21 pusto selo, na vlastelinstvu Ivankovu 2 naseljena i 18 pustih sela itd. ${ }^{7}$

Mažuran je uočio da je već komorski popis iz 1702. godine zabilježio popravljanje stanja u demografskom i gospodarskom pogledu te je u odnosu na 1698. godinu broj domaćinstava i stanovnika u prosjeku porastao za 30\%. ${ }^{8}$ Mažuran stoga procjenjuje da je tada već samo u slavonskom Provincijalu (bez istočnog Srijema) živjelo oko 40-45.000 stanovnika. Tijekom 18. stoljeća stanovništvo Slavonije nastavilo je naglo rasti. U tome rastu važan su čimbenik bile migracije, naročito u vrijeme novog habsburško-osmanskog rata (1716-1718), kada su se doselile mnoge izbjeglice iz Bosne i Srbije.

MAŽURAN 1988: 42.

6 Isto.

7 ISTI 1993: 29.

8 Isto: 43. 
Godine 1736. proveden je još jedan komorski popis slavonskog Provincijala. Prema tome popisu, na prostoru civilne Slavonije i zapadnog Srijema živjelo je tada 14.400 domaćinstava u 509 sela pa je prema procjeni Ive Mažurana broj stanovnika slavonskog Provincijala bio dvostruko veći nego 1702. godine, odnosno iznosio je između 90 i 95 tisuća. ${ }^{9}$ Porast stanovništva u razdoblju od 1702. do 1736. ne može se u potpunosti analizirati jer nedostaju demografski izvori na temelju kojih bi se mogao izračunati prirodni prirast. Međutim, nesumnjivo je poznato da se velik dio toga porasta može također zahvaliti doseljavanju u Slavoniju.

Kao što je već rečeno, prvi val naseljavanja u prvim desetljećima 18. stoljeća obuhvaćao je već naseljena mjesta te prostore koji su bili nastanjeni i antropizirani još prije Velikog bečkog rata, ali su uslijed ratnih zbivanja opustjeli. Većina napuštenih sela bila je naseljena ubrzo nakon smirivanja ratnih sukoba. U tome prvom valu naseljavanja Slavonije najveći broj doseljenika potjecao je iz Bosne i Srbije. Radilo se o velikom doseljavanju kršćanskog (katoličkog i pravoslavnog) stanovništva, koje se još tijekom Velikog bečkog rata odvijalo u svojevrsnoj prisilnoj „razmjeni“ stanovništva jer su kršćani iz Osmanskog Carstva bježali na područje kršćanskih država Habsburške Monarhije i Mletačke Republike, dok je muslimansko stanovništvo s prostora Dalmacije, Like, Slavonije i Ugarske bježalo na prostore koji su bili pod vlašću Osmanlija.

Doseljavanja iz Bosne i Srbije bila su konstantna tijekom čitavog 18. stoljeća. U istočnoj Slavoniji, između Osijeka i Vukovara, naseljeni su u prvoj polovini 18. stoljeća mnogi bosanski i mačvanski Srbi. ${ }^{10} \mathrm{Na}$ drugoj strani, preseljavanje bosanskih Hrvata u Slavoniju odvijalo se tijekom 18. stoljeća duž čitave bosansko-slavonske granice na rijeci Savi. Tako su naselili mnoga posavska sela, kao što su Mačkovac, Dolina, Orubica i Svinjar, a u Slavonski Kobaš preselili su se gotovo svi katolici Bosanskog Kobaša. ${ }^{11}$ Nakon 1740. godine mnogi su bosanski Hrvati također prešli Savu te su se uselili u posavska sela Račinovce, Gunju i Komletince. ${ }^{12}$ Spomenuta slavonska sela uz Savu nisu bila napuštena tijekom Velikog bečkog rata, ali je dolazak novog stanovništva iz Bosne znatno ojačao broj njihovih stanovnika. Migracijski pravac iz Bosne bio je svakako najznačajniji u 18. stoljeću, a bosanski doseljenici ušli su u to vrijeme u velik broj slavonskih sela od zapadne Slavonije sve do Srijema.

Nedugo nakon kraja Velikog bečkog rata, već 1710-ih godina započinje i doseljavanje iz Like, Gorskog kotara i Korduna koje nije bilo potaknuto ratnim sukobima, nego ekonomskim problemima, tj. agrarnom prenaseljenošću navedenih krajeva. U historiografiji poznat je primjer preseljenja 1.111 krajiških vojnika s

\footnotetext{
9 Isto: 73.

10 PAVIČIĆ 1953: 123.

11 Isto: $244-245$

12 Isto: 91.
} 
obiteljima, većinom iz Ogulinske kapetanije te iz Tounjske, Žumberačko-slunjske, Barilovačke i Turanjske kapetanije, koji su se uglavnom odselili u Baranju i Srijem. ${ }^{13}$ Također, poznat je primjer doseljavanja ličkih porodica u Golubince i Slankamen. ${ }^{14}$ No, broj slavonskih i srijemskih naselja u koja su se doseljavali bio je mnogo veći. Ličani su se doseljavali u drugoj polovini stoljeća i u Požeštinu - u mjesta Djedinu Rijeku, Sesvete, Grabarje i Kutjevo. ${ }^{15}$ Hrvati iz Gorskog kotara naseljavali su našički i motičinski kraj 1730-ih godina, također zbog ,suviše gusto nastanjenoga gorskoga kraja“, kako to objašnjava Stjepan Pavičić. ${ }^{16} \mathrm{U}$ orahovičkom kraju goranska struja osnovala je sela Crkvare i Novu Jošavu. ${ }^{17}$ Također, ogulinsko-goranska se struja s manjim brojem Ličana useljavala i u virovitičkom i slatinskom kraju u brojna naselja - Kozice, Bakiće, Meljane, Bačevac, Predrijevo i Suhopolje. ${ }^{18}$ Goranska struja naseljavala je u znatnom broju i pakrački kraj naročito mjesta Sirač, Pakrac, Prekopakru i Španovicu. ${ }^{19}$ Ličani i Gorani također su se u većem broju naselili u Novoj Gradišci i Okučanima. ${ }^{20}$

Sedamdesetih godina 18. stoljeća započinje novo veliko naseljavanje Slavonije i Srijema. Vojne vlasti tada naseljavaju naročito mnogo ljudi u Petrovaradinsku pukovniju u koju je u to doba došlo preko tristo pravoslavnih porodica iz Plaškog i Gomirja. ${ }^{21} \mathrm{U}$ isto vrijeme u Slavoniju i Srijem doselio se i velik broj ljudi iz Dalmacije. Poznata je velika migracija koju je vodio svećenik Vicko (Vincent, Vinko) Čubelić (Ćubelić). Pod njegovim vodstvom brojni su se Dalmatinci iz Imotske krajine i Hercegovci iz zapadne Hercegovine iselili preko Like (Svetog Roka, Gračaca) i Pounja u Slavoniju. ${ }^{22}$ Godine 1779. doveo je Čubelić iz bosanske župe Bukove Gore kod Duvna 400 katolika na Đakovačko vlastelinstvo. ${ }^{23}$ Kronika osječkog franjevačkog samostana sv. Križa piše da je kasnije ponovno pokušao prevesti novu grupu ljudi, ali je bio uhapšen. ${ }^{24}$ Vicko Čubelić je 1781. godine nastavio nagovarati Hercegovce i Dalmatince da se isele u Liku i druge krajeve. ${ }^{25}$

\footnotetext{
13 MOAČANIN 1984:49. O istome iseljavanju pisao je i Karl Kaser u svojem djelu Slobodan seljak i vojnik, naglasivši da je glavni uzrok iseljavanja bila zemljišna oskudica. - KASER 1997: 157.

14 PAVIČIĆ 1953: 93.

15 Isto: 247.

16 Isto: 160

17 Isto.

18 Isto: $180-182$.

19 Isto: 216 i 219

20 Isto: 222.

21 Isto: 90.

22 Isto: 97.

23 Diarium 1916: 87.

24 Isto.

25 PERIČIĆ 1980: 22
} 
Godine 1783. svećenik Antun Novak i diaconus latinus Pavao Napuly također su doveli u Slavoniju oko 800 katolika iz Mletačke Dalmacije. ${ }^{26}$

Jedan od trajnih pravaca doseljavanja tijekom čitavog 18 . stoljeća dolazio je iz njemačkih zemalja. Doseljavanje Nijemaca započelo je odmah nakon oslobođenja od osmanske vlasti. Nijemci su u to vrijeme u velikom broju dolazili u Slavoniju kao pripadnici brojnih habsburških postrojbi, ali prvi stalni naseljenici bili su njemački obrtnici, čije je doseljavanje u početku bilo vrlo čvrsto povezano s potrebama vojske. Tako su prve njemačke zajednice nastale u gradovima koji su bili vojna središta - Petrovaradinu i Osijeku. Najbolji je primjer Osijek, točnije, osječki „unutrašnji grad“ (Innere Stadt), gradska općina unutar zidina Tvrđe. Komorski popis te općine iz 1736. godine pokazuju da je ona u prvoj polovini 18. stoljeća bila gotovo u potpunosti njemačka ${ }^{27}$ Doista, specifičnost njemačkog doseljavanja vidljiva je na brojnim primjerima slavonskih trgovišta u kojima su oni činili važan, često i najveći sloj obrtnika. Zbog njihove umješnosti i brojnih znanja koja su donosili, Nijemci su bili vrlo traženi kolonisti. Na svoja imanja željeli su ih privući mnogi vlastelini. Tako su se Nijemci u prvoj polovini 18. stoljeća doselili na Vukovarsko vlastelinstvo, a u drugoj polovini 18. stoljeća na Rumsko vlastelinstvo i u Požeštinu. Na doseljavanje Nijemaca osvrnuo se tada i Friedrich von Taube u svojem djelu Historische und geographische Beschreibung des Königreiches Slavonien und Herzogthumes Syrmien iz 1777. godine. O naseljavanju Nijemaca Taube je u tome djelu zapisao: „Neki plemići, koji žele naseliti svoja imanja, ne traže od Nijemaca da postanu kmetovi, nego s njima zaključuju ugovor na određeni broj godina, a nakon isteka može ići kao slobodan čovjek ili sklopiti novi ugovor. ${ }^{\text {“'28 }} \mathrm{U}$ osnovi, nakon što su se naselili u Osijek i Petrovaradin, nova naseljavanja Nijemaca bila su organizirana od strane slavonskih vlastelina, koji su ih željeli dovesti u svoja trgovištima radi poticanja razvoja obrta i trgovine.

U odnosu na naseljavanje Nijemaca u Baranju, Bačku i Banat, pravac naseljavanja u Slavoniju i Srijem bio je mnogo slabiji. U Banat je, primjerice, Bečki dvor već u prvoj polovini 18. stoljeća usmjerio velik broj njemačkih kolonista pa je general grof Claudius Florimund Mercy kao predsjednik Zemaljske administracije Banata samo u razdoblju od 1722. do 1726. godine u toj regiji naselio preko 10.000 Nijemaca. ${ }^{29}$ Kasnije je u još dvama valovima doseljavanja u vrijeme Marije Terezije i Josipa II. u Bačku i Banat naseljeno još više od 8.500 njemačkih obitelji. ${ }^{30}$ Dakle, dok se broj naseljenih Nijemaca u Bačkoj, Baranji

\footnotetext{
26 Diarium 1916: 104.

27 MAŽURAN 1993: 94-96.

28 TAUBE 2012: 53.

29 GEIGER 1991: 321.

30

Isto.
} 
i Banatu brojio u desecima tisuća ljudi, u Slavoniji i Srijemu se tijekom čitavog 18. stoljeća radilo o ukupnom broju od najviše 4-5.000 ljudi, što će se u nastavku rada dodatno argumentirati.

Na kraju treba spomenuti još dvije manje migracije - bugarskih katolika Čiprovčana i albanskih katolika. Veliki bečki rat izazvao je veliku migraciju bugarskih katolika iz grada Čiprovaca. Čiprovčani su bili većinom trgovci pa se nisu naselili samo u jednome mjestu, nego pojedinačno u brojnim gradovima Baranje, Bačke i Slavonije. ${ }^{31} \mathrm{Na}$ drugoj strani, u većoj grupi tijekom 1730-ih godina u srijemska sela Nikince i Hrtkovce doseljavaju se Albanci katolici, koji su u tim mjestima ubrzo osnovali svoje trajne zajednice. ${ }^{32}$

\section{Šume kao determinanta demografskog razvoja}

Šumski je pokrov stoljećima predstavljao velik problem naseljavanja i uspostave prometnih komunikacija u Slavoniji. O kolikoj je prirodnoj uvjetovanosti riječ, može se razumjeti ima li se u vidu da su šume prekrivale oko $70 \%$ ukupnog prostora ranonovovjekovne Slavonije. ${ }^{33}$ Vrlo je važan primjer prostora između Orahovice, Našica, Đakova, Valpova i Osijeka, koji je sve do 18. stoljeća bio potpuno prekriven gustim šumama.

Ekološko-geografsku uvjetovanost nastanka sela u prostranim gustim ravničarskim šumama određivala je i voda. Naime, poplavnost područja predstavljala je najveću prepreku naseljavanju pa su se sela gradila na visokim gredama između dubokih šuma. Tako su u ravničarskim prostorima prekrivenim šumama zapravo bila prisutna dva prirodna ograničavajuća čimbenika - šume i vode. Ljudi su se zato naseljavali ondje gdje su oba čimbenika mogli najlakše savladati. Stjepan Pavičić tako piše za prostor između Vuke, Krndije, Papuka, potoka Voćinke i Karašice da se u njemu uglavnom nalazi niže tlo, gusto obraslo šumom, ali da ima mnogo visokih greda na kojima su nastala naselja. ${ }^{34}$ Tako su još u srednjem vijeku nastala sela Hrkanovci i Budimci, a i druga u njihovoj okolici. ${ }^{35}$

Naseljavanje šumskih prostora nužno je moralo uključiti krčenje šuma, što je bio vrlo zahtjevan posao. Trebalo je najprije iskrčiti šume, a zatim iskrčeni prostor pretvoriti u obradive površine. U tome je smislu naročito vrijedno praćenje naseljavanja Đakovačkog vlastelinstva na kojem je tijekom 18. stoljeća čak 2/3

\footnotetext{
31 Među Čiprovčanima najpoznatija je porodica Pejačevića, koja se nakon Velikog bečkog rata naselila najprije u Baju u Bačkoj, a zatim raširila po Bačkoj i Slavoniji. - SKENDEROVIĆ 2017: 113.

32 PAVIČIĆ 1953: 95.

33 KLEPAC 1982: 490.

34 PAVIČIĆ 1953: 154.

35 Isto: 143.
} 
prostora bilo prekriveno šumom pa su đakovački biskupi imali vrlo težak zadatak naseljavanja. ${ }^{36}$ Obnovu Đakovačkog vlastelinstva započeo je biskup Đuro Patačić (1703-1716), ali je veće zahvate učinio tek njegov nasljednik biskup Petar Bakić (1716-1749). ${ }^{37}$ Poznato je da je Bakić započeo i melioraciju i uređivanje vlastelinskoga gospodarstva, ali je krčenje šuma bilo velik izazov u kojem nije imao puno uspjeha jer nije imao dovoljno ljudi za taj posao. ${ }^{38}$ Biskup Bakić je stoga nastojao unaprijediti Đakovačko vlastelinstvo tako što je uredio cestu Brod - Đakovo - Osijek, krčeći šumu uz cestu u širini od pedeset koraka. ${ }^{39}$ Tajni zemljovidi iz 1780-ih godina pokazuju da se još tada u sjeveroistočnom dijelu vlastelinstva šuma prostirala s obiju strana ceste. No, kvalitetna cestovna komunikacija kroz tu šumu omogućila je nastavak naseljavanja i gospodarskog razvoja sjeveroistočnog dijela Đakovačkog vlastelinstva

Rezultati djelovanja biskupa Patačića i Bakića bili su vidljivi, ali je razvoj Đakovačkog vlastelinstva ipak zaostajao za ostatkom slavonskog Provincijala. Demografski su pokazatelji najbolji dokaz. Ive Mažuran tako naglašava da je broj domaćinstava slavonskog Provincijala udvostručen između 1702. i 1736. godine, ali Đakovačko je vlastelinstvo doživjelo u isto vrijeme porast broja domaćinstava od svega $22 \%{ }^{40}$ Teškoće s „osvajanjem“ “šumskog prostora vidljive su i iz činjenice da đakovački biskupi dugo nisu mogli naseliti niti napuštena naselja, dok su se takva naselja u drugim krajevima Slavonije naseljavala ubrzo nakon oslobođenja od osmanske vlasti. Važan primjer kasnog naseljavanja napuštenih sela Đakovačkog vlastelinstva predstavljaju Punitovci, selo koje su se u to doba nalazilo usred velikog šumskog kompleksa. To je selo bilo naseljeno još u srednjem vijeku, a opstalo je i u vrijeme osmanske vladavine pa se može tvrditi da je imalo snažno antropiziranu okolicu s obradivim površinama. No, godine 1683. ono je napušteno i tako je ostalo sve do 1758 . godine - dakle, skoro osam desetljeća. ${ }^{41}$ Punitovce je tek 1758. godine uspio naseliti biskup Josip Antun Čolnić naseljenicima iz Bosne. ${ }^{42}$ Nesumnjivo je da se u osam desetljeća okolna šuma proširila na obradive površine Punitovaca pa su novi doseljenici 1758. godine morali ponovno krčiti nekad antropizirane površine. Pored Punitovaca, Čolnić je tada bosanske Hrvate od Plehana i Dervente naselio i u susjedna sela te je tako uspio „osvojiti“ šumoviti prostor sjeveroistočnog dijela vlastelinstva i privesti ga poljodjelskoj aktivnosti. ${ }^{43}$

\footnotetext{
VRBANUS 2018: 226.

37 SRAKIĆ 1991: 154.

38 Isto.

39 Isto: 155

40 MAŽURAN 1993: 316.

41 MARKOVIĆ 2002: 240.

42 Isto.

43 PAVIČIĆ 1953: 277.
} 
Dio doseljenika naselio je u Beketince u kojima je dotad živjelo nekoliko pravoslavnih porodica. ${ }^{44}$ Kao i Punitovci, tako su se i Beketinci nalazili usred šume pa je tek doseljavanjem novih porodica moglo započeti novo krčenje šuma. ${ }^{45}$ Pored Punitovaca i Beketinaca, sela koja su postojala i u osmansko doba, biskup Čolnić osnovao je i dva potpuno nova sela - Široko Polje i Vuku. Ova su dva naselja bila smještena na cesti Đakovo - Osijek, što je moglo privući nove naseljenike. Na drugoj strani, oko ceste bila je šuma pa je naseljavanje novih naseljenika baš na tim mjestima predstavljalo osnovu za krčenje tamošnjih šumskih prostora iz tih točaka. Biskup Čolnić uspio je u svojoj namjeri jer su sva četiri spomenuta sela zaživjela. No, krčenje okolnih šuma bio je dugotrajan proces koji je trajao čitavo 18. i 19. stoljeće. ${ }^{46}$ Tek je krajem 19. stoljeća taj šumski prostor doista potpuno iskrčen te danas izgleda sasvim drugačije od stanja u prvoj polovini 18. stoljeća.

Skoro osam desetljeća napuštenosti Punitovaca podudara se s primjerom sela Dragotina na istome vlastelinstvu koje je bilo također napušteno od 1683. do 1750-ih godina (prema M. Markoviću, ponovno je bilo naseljeno 1752. godine, a prema S. Pavičiću, 1765. godine, kada je đakovački biskup i u to selo naselio 11 rodova iz Bosne iz derventskog kraja). ${ }^{47}$ Mjesta Punitovci i Dragotin primjeri su duge raseljenosti nekih sela nakon Velikog bečkog rata, pri čemu je jedan od glavnih problema ponovnog naseljavanja bio ekološko-geografske prirode.

\section{Ekološko-epidemiološka determinanta}

Među glavnim problemima demografske obnove Slavonije tijekom 18. stoljeća u historiografiji se uvijek ističe i nezdravost nekih njezinih krajeva, prvenstveno zbog brojnih močvara koje su u to doba postojale. Biserka Belicza piše tako da se Slavonija u Monarhiji smatrala izuzetno nezdravim krajem u kojem su vladale kuga, malarija, tifus, dizenterija, velike i male boginje te druge zarazne bolesti. ${ }^{48}$ Potvrde za takve zaključke donose pisanja tadašnjih suvremenika. Primjerice, Friedrich von Taube zapisao je o zdravstveno-klimatskim prilikama u Slavoniji sljedeće: „I zrak je vrlo različit. U sredini zemlje između brda je bistar, čist i zdrav, ali duž tri glavne rijeke je vrlo nezdrav, budući da se te tri rijeke često nadaleko i naširoko izlijevaju te poplavljuju ravnu zemlju i ostavljaju velike močvare, koje ne samo što pokrivaju $1 / 8$ dio Kraljevine, nego se do pripeke počinju kvariti i zagađuju zrak. Zbog toga nastaju zloćudne groznice koje odnose tako mnogo

\footnotetext{
44 MARKOVIĆ 2002: 237.

45 Isto.

46 Biskup J. J. Strossmayer u 19. stoljeću u tome kraju naselio je još tri sela - Krndiju, Josipovac i Jurjevac - također s ciljem krčenja toga šumskog prostora.

47 MARKOVIĆ 2002: 246; PAVIČIĆ 1953: 279.

48 BELICZA 1991: 294.
} 
ljudi, naročito stranaca, da su Osijek i Petrovaradin nazvani groblje Nijemaca.“49 Taubeove su tvrdnje u osnovi bile točne. Močvara je u Slavoniji bilo puno. Komaraca prijenosnika također. Malarija je u Slavoniji bila endemska bolest, ali o njezinu utjecaju na život Slavonaca u 18. stoljeću malo znamo jer se tada još nije znao njezin uzročnik i nisu se vodile statistike o oboljelima.

Malarija je zarazna bolest koja se prenosi isključivo ubodom malaričnog komarca zaraženog parazitom Plasmodium sp. Danas u Hrvatskoj nema malaričnih područja, ali je do 20. stoljeća ta bolest bila stalno prisutna u kontinentalnoj Hrvatskoj, Dalmaciji i Istri. Slavonija je u 18. stoljeću bila pogodan prostor za širenje malarije jer je imala velike močvarne površine i mnoštvo komaraca roda Anopheles koji prenose tu bolest. U 18. stoljeću medicina još nije znala da malariju prenose komarci. Tadašnji su znanstvenici povezivali malariju s močvarama $\mathrm{i}$ isparavanjima pa $\mathrm{i}$ Taube piše da bolesti nastaju zbog isparavanja poplavljenih i močvarnih prostora. ${ }^{50}$ Radilo se o tada općeprihvaćenoj teoriji mijazme (grč. miasma - 'skrnavljenje'), tj. nezdravog onečišćenja zraka (otuda i talijanski naziv malarija = mal'aria, što znači 'loš, onečišćen zrak'). Malarija je bila problem prisutan i u susjednom Banatu i Bačkoj, krajevima koji su također u 18. stoljeću masovno kolonizirani novim naseljenicima. U Banatu nazivali su je Wechselfieber ili Banater Fieber, ali je općenito u tome prostoru bila zapravo poznata kao barska groznica (Marschenfieber, Sumpffieber). ${ }^{51}$

$\mathrm{Za}$ Banater Fieber je suvremena medicina utvrdila da se doista radilo o malariji. ${ }^{52}$ Ipak, za brojne slučajeve koji su se tumačili kao „epidemije malarije“ tijekom 18. stoljeća ne zna se točno o kakvoj se malariji radilo i je li možda u nekim slučajevima bila riječ o drugim epidemijama. Poznate su, naime, i druge epidemije koje su suvremenici tada nazivali jednostavno groznicama. Prvenstveno se često moglo raditi o nekim epidemijama tifusa koje su tada liječnici u Ugarskoj zvali „ugarskom groznicom“ ili Febris Hungarica.

Malarija je nesumnjivo bila prisutna u slavonsko-srijemskom području u 18. stoljeću, ali danas još uvijek nisu poznati povijesni izvori koji bi mogli kvantitativno pokazati koliki je bio njezin utjecaj. Usporedba sa susjednim zemljama nameće zaključak da je bio vrlo velik. Primjerice, rumunjski znanstvenici tvrde da je malarija u Banatu tijekom 18. stoljeća bila najčešći uzročnik smrti kako domaćeg stanovništva (Rumunja i Srba) tako i koloniziranih Španjolaca koji su zbog toga napustili svoju koloniju Novu Barcelonu. ${ }^{53}$ Kvalitetne podatke o njezinu utjecaju na život u Slavoniji imamo tek od kraja 19. stoljeća. Iz toga razdoblja imamo

\footnotetext{
TAUBE 2012: 22.

50 Isto.

51 POPOVIĆ 1959: 27.

52 NEGHINA ET AL. 2011: 1335.

53 Isto: 1336.
} 
izvješća koja potvrđuju da je malarija bila vrlo ozbiljan zdravstveni problem u osječkom kraju. Najstariji poznati izvor koji nam može kvantitativno pružiti uvid jest izvješće osječke bolnice iz 1879. godine u kojem je zapisano da su te godine liječena 3.404 bolesnika, a od toga da su 743 bolovala od „nastupne groznice“ (malarije) te je za svakog potrošeno 3 grama kinina. ${ }^{54}$ Prema tome izvješću, gotovo svaki četvrti bolesnik osječke bolnice bolovao je od te bolesti.

Dakle, malarija je bila raširena i stalno prisutna. Ipak, već u 18. stoljeću bila je izlječiva. Liječila se kininom koji se u Slavoniji i ugarskom Podunavlju obilato koristio. Pouzdane podatke o njegovu korištenju imamo iz vremena druge polovine 18. stoljeća. Znamo, primjerice, da se koristio u slavonsko-srijemskom prostoru iz pisanja srijemskog županijskog liječnika Martina Marikowzkog, koji spominje kinin pod tada poznatim nazivom Corticus peruvianus (,,peruanska kora“) kao sredstvo liječenja. ${ }^{55}$ Postoje i druge potvrde da je kinin tada bio u raširenoj upotrebi u našim krajevima te u čitavom prostoru Slavonije i ugarskog Podunavlja. Tako, primjerice, Dušan J. Popović navodi da se 1794. godine u temišvarskoj apoteci prodavalo $17-18$ funti $(8-9 \mathrm{~kg})$ kinina dnevno. ${ }^{56}$

\section{Utjecaj malarije na njemačku kolonizaciju Slavonije i Srijema}

Za povjesničare i povjesničare medicine ostaje otvoreno pitanje života domaćeg stanovništva i doseljenika u takvome malaričnom prostoru. Ovdje je u kontekstu njemačke kolonizacije najvažnije pitanje je li doista malarija izazivala velik pomor doseljenih Nijemaca, kao što je to tvrdio Taube.

Njemački kolonizacijski pravac doseljavanja u Slavoniju važan je i zanimljiv iz više razloga. Kao što je već naglašeno, njemačka kolonizacija u Slavoniju bila je tijekom 18. stoljeća mnogo manja nego u susjedne regije Baranju, Bačku i Banat. Prva naseljavanja Nijemaca išla su prema gradovima. Najstarije naseljene zajednice pojavile su se u velikim vojnim centrima - Osijeku i Petrovaradinu. Nakon toga, njemačke su se zajednice počele pojavljivati u manjim trgovištima na privatnim vlastelinstvima. Izvrstan je primjer osnivanje Novog Vukovara 1723., koji su osnovali Nijemci, te je tako čitavo jedno tadašnje prigradsko naselje Vukovara bilo naseljeno njemačkim doseljenicima. ${ }^{57}$ Sličan je primjer organizirano doseljavanje Nijemaca 1745. godine iz Kemptena (u bavarskoj pokrajini Švapskoj) u Daruvar, što je znatno utjecalo na pozitivan razvoj toga trgovišta. ${ }^{58}$

54 JANOŠI 1996: 209.

55 MARIKOWZKY 1767: 67.

56 POPOVIĆ 1959: 27.

57 Ive Mažuran piše da je Novi Vukovar osnovan kao selo, ali je to naselje od početka zapravo funkcioniralo kao prigradsko naselje. - MAŽURAN 1993: 171.

58 HORVAT 1936: 28. 
Kao što je već spomenuto, Nijemci su bili vrlo cijenjeni kao kolonisti jer je i njihova poljoprivredna djelatnost bila naprednija u odnosu na domaće slavonsko stanovništvo. Zbog toga su se u 18. stoljeću naseljavali i na druga slavonska vlastelinstva, ali u malom broju. Nevelike, ali poznate zajednice njemačkih kolonista naseljene su u nekoliko manjih doseljavanja tijekom 18. stoljeća u Požeštini. Najranije naseljavanje proveo je barun Franjo Trenk, koji je naselio manju skupinu Nijemaca u Mihaljevce (Deutsch Mihaljevci) na Brestovačkom vlastelinstvu. Prema Hansu Kühnu, 1750. godine u selu Deutsch Mihaljevci spominju se „nedavno naseljeni kolonisti“, što znači da je mjesto naseljeno svakako prije 1750 ., a negdje u isto vrijeme Trenk je naselio Nijemce i u selu Alaginci. Oko 1770-ih Nijemci su naseljeni i u Eminovcima na Veličkom vlastelinstvu. Naime, u Hrvatskom državnom arhivu čuva se „Popis opustjelih i naseljenih sesija“ iz 1772. godine u kojem piše da su u Eminovce te godine naseljeni "Suevi Catholici“. ${ }^{59}$ Manja naseljavanja Nijemaca provedena su tijekom druge polovine 18. stoljeća i na Kutjevačkom vlastelinstvu u selu Raisavci. ${ }^{60}$

Poznato je i naseljavanje u mjestu Kula na Kutjevačkom vlastelinstvu 1770-ih godina. Tada su se u to selo doselili također Nijemci, koji su ga prozvali Josephsfeld (Josipovo Polje) po caru Josipu II. U isto vrijeme doseljeni su i u susjedno mjesto Poreč na istome vlastelinstvu. Doseljeni Nijemci dobili su 6 jutara oranice i 2 jutra livade te konje, ratarsko oruđe i druge potrepštine za život. ${ }^{61}$ Bili su to dobri uvjeti za početak života i oni su se doista većinom snašli.

U vezi s tim naseljavanjima povijesni izvori nigdje ne spominju ekološkoepidemiološke probleme. Doduše, Požeška županija bila je ipak mnogo manje izložena zaraznim bolestima karakterističnim za močvarno-poplavni prostor u nizinama. Matija Piller i Ljudevit Mitterpacher, profesori Sveučilišta u Budimu koji su 1782. godine putovali u Požešku županiju, opisuju zdravstveno stanje u njoj dosta povoljnim: „U puku nema mnogo bolesti. U kasno ljeto boluju od groznice, u kolovozu i siječnju od dizenterije, u prosincu i siječnju od upale porebrice, u veljači i ožujku od zlopakih groznica. Iako se čini da su uzroci tih bolesti dosta jasni, ipak se ne usuđujemo iznijeti svoje mišljenje. Od lijekova što ih narod upotrebljava mogli smo uglavnom doznati za ove: glavni lijek protiv groznice je kičica. Njezino lišće i cvijeće, koliko se može zahvatiti s tri prsta, kuhaju malo izmrvljeno u vodi na slaboj vatri. Ako se taj lijek pije natašte, vele da krijepi želudac i goni groznicu." ${ }^{62}$

U Virovitičkoj su županiji u drugoj polovini 18. stoljeća također osnovana sela Lukač i Suhopolje-Terezovac u koja su naseljeni Nijemci. Prema Sundhaussenu,

\footnotetext{
59 HR-HDA-29, Požeška županija, Rescripta Comitatus, kut. XLIV (1772), No. 15.

60 KÜHN 1936: 11.

61 WITTENBERG 2002: 68.

62 PILLER I MITTERPACHER 1995: 153 i 155
} 
Lukač je naseljen 1750., a Suhopolje 1770. godine. ${ }^{63}$ Pored toga, poznato je da su u drugoj polovini 18. stoljeća Nijemci naseljavali i Deutsch-Bresniz kod Našica. ${ }^{64}$ Sundhaussen navodi i da su Nijemci 1769. naselili mjesta Hirschfeld (Sarvaš) i Krawitz (Josipovac), a 1770. Deutsch Rietdorf (Njemačka Retfala) ${ }^{65}$

Povijesno je najveći ekološko-epidemiološki problem njemačkog naseljavanja tijekom 18. stoljeća u našim krajevima zabilježen u Srijemu, i to konkretno u Rumi na Rumskom vlastelinstvu. U naseljavanju Nijemaca na to vlastelinstvo glavnu je ulogu imao Marko Pejačević, najprije zakupnik, a kasnije i vlasnik tadašnjeg Mitrovačkog vlastelinstva. Kada je godine 1745. Srijemska Mitrovica pripala Vojnoj granici, Marko Pejačević želio je osnovati novo središte svoga vlastelinstva - Novu Rumu (uz nju je bilo selo Ruma, tj. stara Ruma koja je samostalno postojala do 1776., kada je priključena novoj Rumi). ${ }^{66}$ Pejačević je od Marije Terezije dobio dopuštenje za izgradnju trgovišta Rume, ali ga je morao naseliti novim kolonistima.

Prema Slavku Gavriloviću, u razdoblju od 1746. do 1750. u Rumu su se doselile 173 njemačke porodice sa 628 duša ${ }^{67}$ Prvi su se njemački doseljenici doselili pod vrlo dobrim uvjetima: dobili su od vlastelinstva zemlju i pomoć za gradnju kuća, a Pejačević je svakoj obitelji nabavio i po dva konja i jednu kravu. ${ }^{68}$ Doseljavanje Nijemaca u Rumu u to je doba bilo najveće zabilježeno na slavonsko-srijemskom području.

Prvi udarac njemačka je zajednica doživjela 1748. godine, kada je, prema Gavriloviću, „neka malarija“ pokosila preko 150 Nijemaca. ${ }^{69}$ Marko Pejačević namjeravao je od Rume napraviti trgovište s 1.500 kuća, ali nesretna 1748. godina znatno je oslabila nade da će to ostvariti. Kasniji događaji doveli su do toga da planirani broj naseljenih domaćinstava uopće nije bio ostvaren tijekom 18. stoljeća. Već 1762. godine umire sâm Marko Pejačević. Njegov nasljednik na Rumskom vlastelinstvu bio je njegov rođak Josip Pejačević, koji se 1765. iz Našica čak preselio u Rumu kako bi osobno preuzeo vođenje toga vlastelinstva. ${ }^{70} \mathrm{Ni}$ Josip Pejačević nije uspio naseliti 1.500 kuća u Rumi, premda je predano radio na tome, a jednom se čak otvoreno žalio Srijemskoj županiji da ne može naći koloniste, iako ih njegovi ljudi neumorno nastoje vrbovati po Njemačkoj. ${ }^{71}$

\footnotetext{
63 I prema Wilhelmu Sattleru, Nijemci su u Suhopolje vjerojatno naseljeni već 1770. godine. SATTLER 1938: 533.

64 Isto: 550.

65 SUNDHAUSSEN 1995: 295.

66 GAVRILOVIĆ 1969: 12.

67 Isto: 13.

68 Isto.

69 Isto: $13-14$.

70 Isto: 18.

71 Isto: 41.
} 
Novu priliku dobio je tek Josipov sin Karlo, koji Rumskim vlastelinstvom upravlja od 1780. godine i nastavlja napore svojih prethodnika Marka i Josipa. Tijekom 1780-ih godina izgledalo je da će dugogodišnji Pejačevićevi napori konačno dati rezultate jer je Karlo Pejačević tada uspio dovesti velik broj njemačkih kolonista. Naime, sâm car Josip II. potaknuo je 1780-ih godina još jedno masovno naseljavanje Nijemaca u Slavoniju i ugarsko Podunavlje. U sklopu toga u Rumu je 1786. godine stigla nova velika skupina Nijemaca. Točnije, prema Slavku Gavriloviću, stiglo je 559 njemačkih porodica koje su brojile 2.439 duša. ${ }^{72}$ Međutim, nisu izvedene dobre pripreme za njihov prihvat. Zapravo, pripreme su obavljene katastrofalno pa je dolazak ovog velikog broja doseljenika pretvoren u pravu katastrofu. ${ }^{73}$ Doseljenici su ostali prepušteni sami sebi te su se našli izloženi gladi i neimaštini. Na kraju su mnogi bili prisiljeni čak i prosjačenju kako bi preživjeli. Teški uvjeti u kojima su se našli doveli su do izbijanja malarije i difterije, što je rezultiralo velikim brojem smrtnih slučajeva, naročito djece, pa je tada umrlo 338 ljudi. $^{74}$

Uz temu utjecaja malarije na njemačko stanovništvo, ne može se ne spomenuti događaje iz ratnih zbivanja 1788. godine. Kada je Habsburška Monarhija 9. veljače 1788. objavila rat Osmanskom Carstvu, znalo se da će jedno od glavnih mjesta sukoba biti Beograd. Zato je Josip II. središnji dio svoje vojske smjestio između Petrovaradina i Zemuna. Ukupno je u tome ratu okupio ogromnu vojsku od 294.173 vojnika. ${ }^{75}$ Početkom travnja 1788. i sâm je stigao u vojni logor kod Zemuna. Procjene veličine glavne armije u Srijemu uglavnom se slažu da je na tome prostoru tada bilo nešto više od 100.000 vojnika. ${ }^{76} \mathrm{U}$ lipnju 1788. izbila je među vojnicima epidemija. Nije točno jasno je li izbila malarija jer je moguće da su među vojnicima bile prisutne i druge zarazne bolesti - dizenterija i tifus. Zna se da je u vojnom logoru kod Zemuna bilo 7.000 oboljelih krajem lipnja 1788. ${ }^{77}$ Također, zna se da je tada već i sâm car obolio od dijareje. ${ }^{78}$ Krajem srpnja broj oboljelih vojnika povećao se na više od 23.000, a bilo je i preko 700 smrtnih slučajeva. ${ }^{79} \mathrm{U}$ kolovozu car je s dijelom vojnika smještenih u Srijemu otišao na bojište u Banat te se nakon toga ujesen iste godine vratio. Helmut Reinalter, biograf Josipa II., tvrdi da je ujesen 1788. car obolio od tuberkuloze, a u isto vrijeme i od malarije.$^{80}$ Krajem 1789. zdravlje Josipa II. još se više pogoršalo i dovelo do

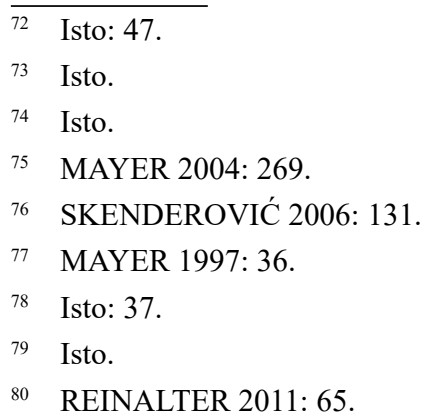


toga da je umro 20. veljače 1790. od komplikacija izazvanih tuberkulozom. Iako se ne zna pouzdano jesu li vojnici u Zemunu i Srijemu oboljeli od malarije, taj je slučaj ipak pokazatelj koliko su epidemije vezane uz močvarno-poplavne krajeve bile velika prijetnja za stanovništvo.

\section{Zaključak}

Veliko naseljavanje i velik porast stanovništva Slavonije tijekom 18. stoljeća najvećim su dijelom posljedica stalnog naseljavanja novih kolonista - kako u Slavonsku vojnu granicu tako i u slavonski Provincijal. Brojni su čimbenici utjecali na brzinu i razmjere toga naseljavanja. U ovome radu obrađeni su ekološko-geografski utjecaji.

Popis iz 1698. pokazuje da su mnoga sela na kraju Velikog bečkog rata ostala napuštena i da su širom Slavonije bile prisutne velike šume. Štoviše, naglo smanjenje broja stanovnika dovelo je do toga da se šuma u mnogim krajevima Slavonije širila tijekom razdoblja od 1680-ih do prvih desetljeća 18. stoljeća, a u nekim primjerima i do 1750-ih godina. Primjer Đakovačkog vlastelinstva pokazuje kako je na jednom takvom vrlo šumovitom vlastelinstvu trajao proces ponovnog „osvajanja“, odnosno antropizacije velikih šumskih prostora. Antropizacija je kretala od glavnih cestovnih komunikacija prema unutrašnjosti šumskih kompleksa. Biskup Bakić učvrstio je cestovnu komunikaciju Đakovo - Osijek kroz šumski pojas sječom šuma s lijeve i desne strane ceste. Zatim je njegov nasljednik, biskup Čolnić, naselio nove naseljenike na toj cesti i u obližnjim selima koji su u sljedećim desetljećima radili na krčenju šuma u tome dijelu Đakovačkog vlastelinstva.

Na drugoj strani, ekološko-epidemijski problemi bili su prisutni u močvarnim krajevima osječke okolice i Srijema. Poznati slučajevi većeg pobola stanovništva naseljenog u močvarno-poplavnim prostorima vezani su uz gradove Osijek i Petrovaradin te uz naseljavanje Nijemaca u Rumi. Primarna prijetnja u tim krajevima bila je malarija. Nažalost, navedeni primjeri nemaju dovoljno izvora na temelju kojih bi se mogli utvrditi neki kvantitativni pokazatelji obolijevanja i smrtnosti od malarije. Jedino se sa sigurnošću može tvrditi da je malarija u tim prostorima bila prisutna u 18. stoljeću i da se liječila kininom. Kasniji dokumentirani podaci s kraja 19. stoljeća otkrivaju da je u Osijeku malarija doista predstavljala vrlo velik zdravstveni problem pa se onda može projicirati da je u 18. stoljeću bila još veći. Usprkos navedenim činjenicama, broj stanovnika Slavonije, Osijeka, Rume i Srijema rastao je tijekom čitavog 18. stoljeća. Tomu je pomagalo sve bolje uređenje javnog zdravstva, porast broja školovanih doktora medicine, bolničkih kapaciteta i opskrbe lijekovima, a i zahvati u okoliš, naročito isušivanje močvara. 


\section{Bibliografija}

\section{Neobjavljeni izvori}

Hrvatski državni arhiv

HR-HDA-29, Požeška županija, Rescripta Comitatus, kut. XLIV (1772)

\section{Objavljeni izvori}

Diarium 1916: Diarium sive prothocollum conventus S. Crucis Inventae Essekini, ur. Josip Bösendorfer. Starine JAZU 35: 1-198.

MARIKOWZKY, Martinus. 1767. Ephemerides Sirmienses seu observationes physicomedicae. Vindobonae.

MAŽURAN, Ive. 1988. Popis naselja i stanovništva u Slavoniji 1698. godine [Radovi Zavoda za znanstveni rad JAZU u Osijeku, knj. 2]. Osijek: JAZU, Zavod za znanstveni rad.

MAŽURAN, Ive. 1993. Stanovništvo $i$ vlastelinstva u Slavoniji i njihova ekonomska podloga 1736. godine [Radovi Zavoda za znanstveni rad HAZU u Osijeku, knj. 6]. Osijek: JAZU, Zavod za znanstveni rad.

PILLER, Matija, Ljudevit MITTERPACHER. 1995. Putovanje po Požeškoj županiji u Slavoniji 1782. god. Osijek: Matica hrvatska Požega, Povijesni arhiv u Osijeku.

\section{Literatura}

BELICZA, Biserka. 1991. Zdravstvo i zdravstvene prilike Slavonije u 18. stoljeću. Peti znanstveni sabor Slavonije i Baranje: zbornik radova (Vinkovci, 22. i 23. listopada 1987.), sv. 1, ur. Dušan Čalić, Đuro Berber, 293-304. Osijek: JAZU, Zavod za znanstveni rad.

BRAUDEL, Fernand. 1992. Strukture svakidašnjice. Zagreb: August Cesarec.

DELORT, Robert, François WALTER. 2002. Povijest europskog okoliša. Zagreb: Barbat.

FÜRST-BJELIŠ, Borna. 1998. Triplex Confinium - an Eco-Historic Draft. Microhistory of the Triplex Confinium. International Project Conference Papers 1, ur. Drago Roksandić, 147-155, Budapest: Central European University.

GAVRILOVIĆ, Slavko. 1969. Ruma trgovište u Sremu 1718-1848/49. Novi Sad: Matica srpska.

GEIGER, Vladimir. 1991. Nijemci u Hrvatskoj. Migracijske teme 7/3-4: 319-334.

HORVAT, Rudolf. 1936. Slavonija, knj. I. Zagreb: Tipografija.

JANOŠI, Krešimir. 1996. Zdravstvo. Od turskog do suvremenog Osijeka, ur. Julijo Martinčić, 204-217. Osijek: Zavod za znanstveni rad HAZU, Gradsko poglavarstvo Osijek, Školska knjiga.

KASER, Karl. 1997. Slobodan seljak $i$ vojnik, knj. I. Zagreb: Naprijed.

KLEPAC, Dušan. 1982. Hrastove šume u Slavoniji. Šumarski list 106/11-12: 489-499.

KÜHN, Hans. 1936. Die Besiedlung von Kula und Poreč auf der Kameralherrschaft Kutjevo mit Einwanderern aus dem Deutschen Reiche in den Jahren 1785-1787. 
Beiträge zur Geschichte der deutschen Siedlungen in der ehemaligen Gespanschaft Požega. Zagreb: Selbstverl.

MARKOVIĆ, Mirko. 2002. Slavonija: povijest naselja i podrijetlo stanovništva. Zagreb: Golden marketing.

MAYER, Matthew Z. 1997. Joseph II and the campaign of 1788 against the Ottoman Turks. Master's thesis, McGill University (Montreal, Quebec, Canada).

MAYER, Matthew Z. 2004. The Price for Austria's Security: Part I. Joseph II, the Russian Alliance, and the Ottoman War, 1787-1789. The International History Review 26/2: 257-299.

MOAČANIN, Fedor. 1984. Vojna krajina do kantonalnog uređenja 1787. godine. U Vojna krajina: povijesni pregled - historiografija-rasprave, ur. Dragutin Pavličević, 23-56. Zagreb: Sveučilišna naklada Liber.

NEGHINA, Raul, Adriana M. NEGHINA, Iosif MARINCU, Ioan IACOBICIU. 2011. Epidemiology and history of human parasitic diseases in Romania. Parasitology Research 108/6: 1333-1346.

PAVIČIĆ, Stjepan. 1953. Podrijetlo hrvatskih i srpskih naselja i govora u Slavoniji [Djela JAZU, knj. 47]. Zagreb: JAZU.

PERIČIĆ, Šime. 1980. Dalmacija uoči pada Mletačke Republike. Zagreb: Sveučilišna naklada Liber.

POPOVIĆ, Dušan J. 1959. Srbi u Vojvodini. Novi Sad: Matica srpska.

REINALTER, Helmut. 2011. Joseph II. Reformer auf dem Kaiserthron. München: Verlag C. H. Beck.

SATTLER, Wilhelm. 1938. Umvolküngsvorgänge beim Deutschtum in Slawonien. Südostdeutsche Forschungen 3: 525-562.

SKENDEROVIĆ, Robert. 2006. Bilješke Josipa Paviševića o protuturskom ratu Josipa II. 1788.-1791. Zbornik o Josipu Paviševiću: radovi sa znanstvenog skupa održanog u Osijeku 2002. godine, ur. Ana Pintarić, Franjo Emanuel Hoško, 127-140. Osijek: Sveučilište Josipa Jurja Strossmayera u Osijeku, Hrvatska franjevačka provincija sv. Ćirila i Metoda.

SKENDEROVIĆ, Robert. 2017. Povijest podunavskih Hrvata (Bunjevaca i Šokaca) od doseljavanja do propasti Austro-Ugarske Monarhije. Subotica-Slavonski Brod: Zavod za kulturu vojvođanskih Hrvata, Hrvatski institut za povijest - Podružnica za povijest Slavonije, Srijema i Baranje.

SRAKIĆ, Marin. 1991. Ponovna uspostava i uređenje vlastelinstva bosansko-đakovačke biskupije. Peti znanstveni sabor Slavonije i Baranje: zbornik radova (Vinkovci, 22. i 23. listopada 1987.), sv. 1, ur. Dušan Čalić, Đuro Berber, 151-163. Osijek: JAZU, Zavod za znanstveni rad.

SUNDHAUSSEN, Holm. 1995. Die Deutschen in Kroatien-Slawonien und Jugoslawien. Land an der Donau (= Deutsche Geschichte im Osten Europas), ur. Günter Schödl, 291-348. Berlin: Siedler Verlag.

VRBANUS, Milan. 2018. Šume u komorskim popisima Slavonije i njihovo značenje u gospodarstvu slavonskih vlastelinstava od kraja osmanske vlasti do sredine 18. stolje- 
ća. Slavonske šume kroz povijest: zbornik radova znanstvenog skupa s međunarodnim sudjelovanjem održanog u Slavonskom Brodu 1. - 2. listopada 2015., ur. Dinko Župan, Robert Skenderović, 193-246. Slavonski Brod: Hrvatski institut za povijest-Podružnica za povijest Slavonije, Srijema i Baranje.

WITTENBERG Tomislav. 2002. Sesvetački kraj u srcu Poljadije. Požega: Bolta. 


\section{Ecological-Geographical Determination of Colonization of Slavonia in the $18^{\text {th }}$ Century}

By the end of the $17^{\text {th }}$ century started a new colonization of Slavonia. It was also a new phase of anthropization that lasted until mid- $19^{\text {th }}$ century. At the beginning newly arrived settlers colonized villages that were devastated and abandoned during the Habsburg-Ottoman War of 1683-1699. At the beginning of the $18^{\text {th }}$ century a process of establishing of new villages started. Settlers were arriving from different regions. The strongest migration route went from Bosnia and Serbia. Other settlers arrived from Lika and Gorski kotar, central Croatia, Bačka and Baranja. Migration from German lands was significant as well. Germans, however, settled in relatively small number, comparing to their migration to Baranja, Bačka and Banat. Looking from perspective of ecological geography and environmental history most paradigmatic examples of colonization in Slavonia at that time are colonization of the forest area at the Đakovo Estate and colonization of Germans in the plain swamp area of Osijek and Srijem. Those two examples demonstrate important impact of ecologicalgeographical determination of the colonization of Slavonia in the $18^{\text {th }}$ century.

Anthropization of the forest area at the Đakovo Estate started by establishing new villages on the road Đakovo-Osijek and resettling two other villages nearby in the woods. On the other hand, the main problem of colonization in the plain swamp was ecological-epidemiological. The presence of infectious diseases, mostly malaria, posed a constant threat to the inhabitants and new settlers. Historical sources show that malaria existed in Slavonia during the $18^{\text {th }}$ century and that it influenced colonization of Germans in Osijek and Ruma. There is evidence that quinine was used as a cure against malaria in Slavonia already in the second half of the $18^{\text {th }}$ century. Besides all the problems produced by ecological-geographical and ecological-epidemiological factors, the number of inhabitants of Slavonia and Srijem continued to grow throughout the $18^{\text {th }}$ century, predominantly due to improving of public health institutions, increasing in number of doctors of medicine, hospital capacities and drug supply, and changing of natural environment, mostly by draining swamps.

Keywords: Slavonia, 18th century, colonization, anthropization, forest, swamp, malaria Ključne riječi: Slavonija, 18. stoljeće, kolonizacija, antropizacija, šume, močvare, malarija

Robert Skenderović Hrvatski institut za povijest Podružnica za povijest Slavonije, Srijema i Baranje HR-35000 Slavonski Brod rskender@isp.hr 


\section{FILOZOFSKI FAKULTET SVEUČILIŠTA U ZAGREBU \\ ZAVOD ZA HRVATSKU POVIJEST \\ INSTITUTE OF CROATIAN HISTORY \\ INSTITUT FÜR KROATISCHE GESCHICHTE}

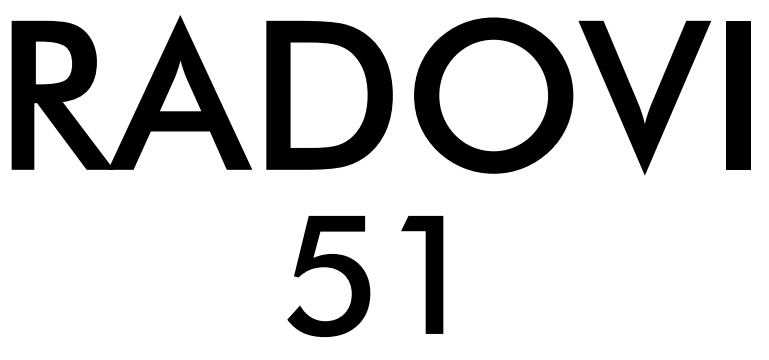

BROJ 1

ZAVOD ZA HRVATSKU POVIJEST

FILOZOFSKOGA FAKULTETA SVEUČILIŠTA U ZAGREBU

\section{FF press}

ZAGREB 2019. 


\section{Poseban broj}

Između Europe i Bliskog istoka: migracije i njihove posljedice na području Jugoistočne Europe $i$

Anadolije u transimperijalnom $i$ interkulturalnom kontekstu

\section{Special issue}

Between Europe and Middle East: Migrations and Their Consequences in Southeast Europe and Anatolia in Transimperial and Intercultural Context 


\title{
RADOVI ZAVODA ZA HRVATSKU POVIJEST FILOZOFSKOGA FAKULTETA SVEUČILIŠTA U ZAGREBU
}

\author{
Knjiga 51, broj 1
}

\author{
Izdavač / Publisher \\ Zavod za hrvatsku povijest \\ Filozofskoga fakulteta Sveučilišta u Zagrebu \\ FF-press \\ Za izdavača / For Publisher \\ Vesna Vlahović Štetić \\ Glavni urednik / Editor-in-Chief \\ Inga Vilogorac Brčić \\ Gostujući urednik / Guest Editor \\ Vjeran Kursar \\ Uredništvo / Editorial Board
}

Jasmina Osterman (stara povijest/ancient history), Trpimir Vedriš (srednji vijek/medieval

history), Hrvoje Petrić (rani novi vijek/early modern history), Željko Holjevac (moderna povijest/

modern history), Tvrtko Jakovina (suvremena povijest/contemporary history), Silvija Pisk

(mikrohistorija i zavičajna povijest/microhistory and local history),

Zrinka Blažević (teorija i metodologija povijesti/theory and methodology of history)

Međunarodno uredničko vijeće / International Editorial Council

Denis Alimov (Sankt Peterburg), Živko Andrijašević (Nikšić), Csaba Békés (Budapest), Rajko

Bratož (Ljubljana), Svetlozar Eldarov (Sofija), Toni Filiposki (Skopje), Aleksandar Fotić

(Beograd), Vladan Gavrilović (Novi Sad), Alojz Ivanišević (Wien),

Egidio Ivetić (Padova), Husnija Kamberović (Sarajevo), Karl Kaser (Graz),

Irina Ognyanova (Sofija), Géza Pálffy (Budapest), Ioan-Aurel Pop (Cluj),

Nade Proeva (Skopje), Alexios Savvides (Kalamata), Vlada Stanković (Beograd),

Ludwig Steindorff (Kiel), Peter Štih (Ljubljana)

Izvršni urednik za tuzemnu i inozemnu razmjenu /

Executive Editor for Publications Exchange

Martin Previšić

Tajnik uredništva / Editorial Board Assistant

Dejan Zadro

Adresa uredništva/Editorial Board address

Zavod za hrvatsku povijest, Filozofski fakultet Zagreb, Ivana Lučića 3, HR-10 000, Zagreb Tel. ++385 (0)1 6120191

Časopis izlazi jedanput godišnje / The Journal is published once a year

Časopis je u digitalnom obliku dostupan na / The Journal in digital form is accessible at

Portal znanstvenih časopisa Republike Hrvatske „Hrčak“ http://hrcak.srce.hr/radovi-zhp

Financijska potpora za tisak časopisa / The Journal is published with the support by Ministarstvo znanosti, obrazovanja i športa Republike Hrvatske

Časopis je indeksiran u sljedećim bazama / The Journal is indexed in the following databases: Directory of Open Access Journals, EBSCO, SCOPUS, ERIH PLUS, Emerging Sources Citation Index - Web of Science 


\title{
Naslovna stranica / Title page by Marko Maraković
}

\section{Grafičko oblikovanje i računalni slog / Graphic design and layout Marko Maraković}

\author{
Lektura / Language editors \\ Samanta Paronić (hrvatski / Croatian) \\ Edward Bosnar (engleski / English)
}

Tisak / Printed by

Tiskara Zelina, Sv. Ivan Zelina

Naklada / Issued

200 primjeraka / 200 copies

Ilustracija na naslovnici

Muza Klio (Alexander S. Murray, Manual of Mythology, London 1898)

Časopis je u digitalnom obliku dostupan na Portalu znanstvenih časopisa Republike Hrvatske ,Hrčak“ http://hrcak.srce.hr/radovi-zhp

The Journal is accessible in digital form at the Hrcak - Portal of scientific journals of Croatia http://hrcak.srce.hr/radovi-zhp 